Diabetologia 7, 386-390 (1971)

(C) by Springer-Verlag 1971

\title{
Failure of Appearance of Insulin Antibodies in Dogs Adapted to Bovine-Porcine Insulin
}

\author{
Ruth Menzel, S. Knospe, M. Znegler, W. Wieke and R. Mrohafe \\ Zentralinstitut für Diabetes, ,Gerhardt Katsch" Karlsburg, DDR \\ Bereich experimentelle Diabetesforschung
}

Received: Fobruary 15, 1971, accepted: July 27, 1971

\begin{abstract}
Summary. 1. After a slowly increased adaptation to insulin (commercial normal insulin, i.e. a mixture of bovine-porcine insulin) two dogs showed no circulating insulin antibodies, despite daily subcutaneous application of $4 \mathrm{IU} / \mathrm{kg}$ body weight for more than 2 years. -2 . The non-appearance of circulating insulin antibodies was confirmed by several experiments in vitro and in vivo especially by autoradiography - immunoelectrophoresis and determination of IBC before as well as after the removal of insulin from the serum. - 3. The biological activity of unlabelled bovine insulin after I.V. injection was not diminished in the dogs adapted to insulin.
\end{abstract}

Non-apparition d'anticorps anti-insuline chez des chiens adaptés à de l'insuline bovine et porcine.

Résumé. 1. Après une adaption. lentement progressive à l'insuline (insuline normale du commerce, mélange d'insulines de boeuf et de pore), deux chiens n'ont montré aucun anticorps circulant contre l'insuline, malgré l'application quotidienne sous-cutanée de $4 \mathrm{IU} / \mathrm{kg}$ durant plus de deux ans. - 2. La non-apparition d'anticorps circulants contre l'insuline a été confirmée par plusieurs expériences in vitro et in vivo, en particulier par autoradiographie - immunoélectrophorèse et détermination
d'IBC aussi bien avant qu'après avoir retiré l'insuline du sérum. - 3. L'activité biologique de l'insuline de boeuf non marquée, après l'injection intra-veineuse, n'a pas diminué chez les chions adaptés à l'insuline.

Fehlen von Insulinantikörpern bei an Rinder- und Sohweininsulin angepaßien Hunden.

Zusammenfassung. 1. Nach einer langsam ansteigenden Anpassung an Insulin (kommerzielles Alt-Insulin, eine Mischung von Rinder- und Schweineinsulin) zeigten 2 Hunde keine zirkulierenden Insulinantikörper, obwohl 4. IF/kg Körpergewicht über zwei Jahre täglich subcutan injiziert wurden. - 2. Das Fehlen von zirkulierenden Insulinantikörpern wurde durch verschiedene Experimen. te in vitro und in vivo, insbesondere durch Autoradio. graphie - Immunelektrophorese und Bestimmung der IBC vor und nach Entfernung des Insulins aus dem Serum bekräftigt. - 3. Die biologische Aktivität unmarkierten Rinderinsulins war nach i.v.-Injektion bei den adaptierten Hunden nicht vermindert.

Key-words: Insulin antibodies, immunotolerance, mode of insulin application.
Preliminary experiments [12] showed that insulin antibodies could not be detected in the serum of insulin-treated dogs, though the animals received subcutaneous injections of commercial normal insulin (bovine-porcine) daily for two years. The special method of treatment consisted in beginning with slowly increasing doses, and in the uninterrupted further application of insulin. We have since concentrated on further methods in vitro and in vino in the same animals to make sure that there were really no antibodies.

\section{Material}

2 adult mongrel dogs were given $3 \times 14 \Pi U$ of commereial normal insulin $/$ day $^{1}(3.5-4.2 \mathrm{IU} / \mathrm{kg}$ body weight per day) after a slowly increasing initial application. First, one subcutaneous injection of 2 IU was given daily for a week. In the second week $2 \times 2 \mathrm{IO} /$ day ( 7 a.m., 12 a.m.) were given, in the third week $3 \times 2 \mathrm{IU} /$ day (7 a.m., 12 a.m., 6 p.m.), in the fourth week $4 \mathrm{IU}+2 \mathrm{IU}+2 \mathrm{IU}$ daily. We increased the in-

1 Alt-Insulin (VEB Berlin-Chemie, $40 \mathrm{IU} / \mathrm{ml}$, mixture of bovine and porcine insulin. sulin dose weekly up to the described one because the dogs then showed more convulsions and anorexia. We called these dogs "adapted to insulin". After about 30 months during which they continuously got insulin three times a day, we performed the experiments in vitro and in vivo, always $18 \mathrm{~h}$ after an injection of insulin.

The control groups consisted of 3 mongrel dogs never treated with insulin, and 3 mongrel dogs im. munized against bovine insulin in adjuvant [11]. The experiments were started four months after the second immunization.

Some of the results were compared with those obtained from a spontaneously diabetic $\operatorname{dog}^{2}$, which received about $4 \mathrm{IU}$ of normal insulin $/ \mathrm{kg}$ body weight, divided in three injections per day.

\section{Methods}

Analytical procedures in vitro for detection of circulating insulin antibodies. Some of the principles and

2 We should like to thank Dr. U. Fischer and his coworkers [6] for giving us the serum of this dog. 
techniques, i.e. Ouchterlony diffusion test [15], immunoelectrophoresis-autoradiography and filtration with Sephadex G-200 [2] have been described in detail previously $[11,12]$. The ${ }^{125} \mathrm{I}$-insulin binding capacity (IBC) in serum was determined by ethanol precipitation of bound insulin [20] and by cellulose differential adsorption of free insulin [7]. $0.2 \mathrm{ml}$ of varying dilutions of serum were incubated for $18 \mathrm{~h}$ at $4^{\circ} \mathrm{C}$ with $0.1 \mathrm{ml}$ of ${ }^{125} \mathrm{I}$-bovine insulin (Isocommerz, $25 \mu \mathrm{U} / \mathrm{ml}$, specific activity $60 \mathrm{mCi} / \mathrm{mg}$ ) for ethanol precipitation. Correspondingly, $0.8 \mathrm{ml}$ of varying dilutions of serum together with $100 \mathrm{mg}$ cellulose MN 100 (Macherey,
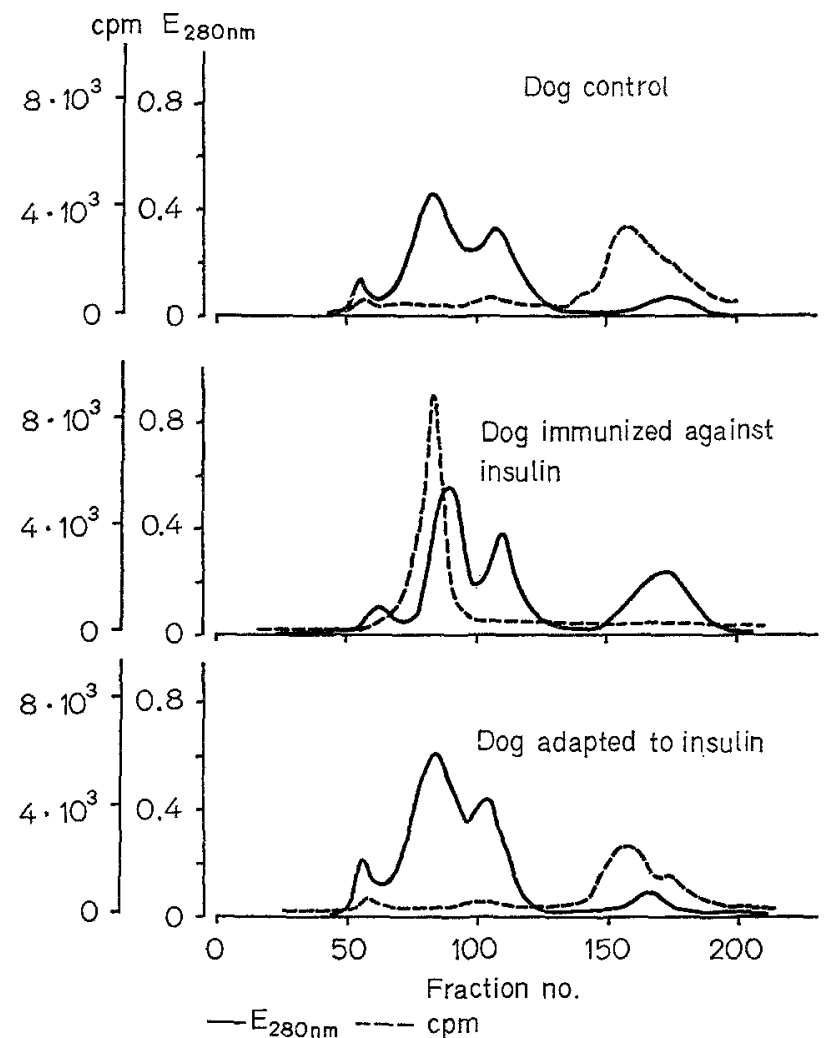

Fig. 1. Elution diagram of gel filtration on Sephadex G-200. Sera of dogs incubated with ${ }^{125}$ I-insulin

Nagel and $\mathrm{Co}$ ) were incubated with $0.2 \mathrm{ml}$ of ${ }^{125 \mathrm{~T}}$ bovine insulin $(50 \mu \mathrm{U} / \mathrm{ml})$. Serum and ${ }^{125} \mathrm{I}$-insulin were diluted with 0.04 M phosphate buffer ( $\mathrm{pH}$ 7.4) $0.3 \%$ human albumin $-2 \% \mathrm{NaCl}$. After separation of bound ${ }^{125} \mathrm{I}$-insulin from free ${ }^{125} \mathrm{I}$-insulin and the subsequent determination of the radioactivity in supernatant (crystal scintillation counter, VEB Vakutronik) the antibody-titre could be determined graphically (semilogarithmic plot of $\mu l$ serum content per sample versus percentage of radioactivity). The IBC was expressed in $\mu \mathrm{U} / \mathrm{ml}$ serum.

Since we could not exclude the possibility that all insulin-binding sites of antibodies were saturated by the daily injected insulin, we separated insulin from protein by fractionating the serum on Sephadex G-100 column with HCl-glycine buffer $(0.75 \%, \mathrm{pH} 2.4)$.
Protein concentrations were recorded by Uvicord (LKB Producter Stockholm). After concentrating the protein fractions by pressure filtration (Sartorius) and by dry Sephadex G-50 in dialysis tube, we carried out autoradiography and determined IBC (ethanol precipitation).

Experiments in vivo for detection of circulating insulin antibodies. All studies were performed without anaesthesia after an overnight fast of $12 \mathrm{~h}$.

1. Intravasal disappearance rate of injected ${ }^{125} \mathrm{I}$ insulin: To provide a good possibility for comparing the results, the experiments were carried out on three siblings (one dog adapted to insulin, one immunized against it and one without any insulin-treatment) with the same fresh solution of ${ }^{125}$ I-insulin lyophilizate $(0.9 \mu \mathrm{Ci} / \mathrm{kg}$ body weight) on the same day. The labelled insulin was administered by rapid injection via a foreleg vein. Samples were obtained from a hindleg vein $1,2,3,4,5,7,10,15,30,45,60,90,120$ min after

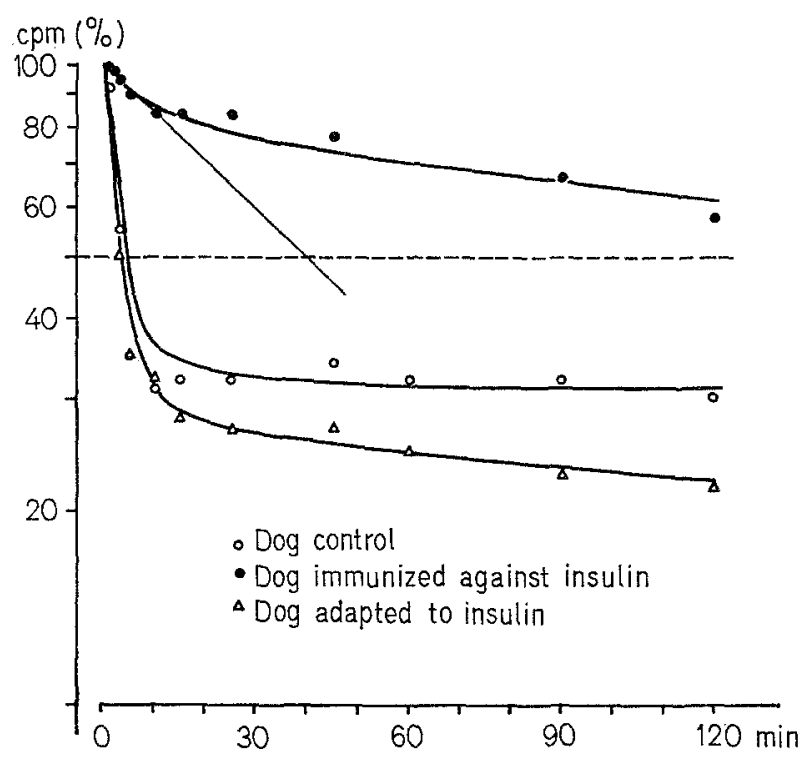

Fig. 2. Intravasal disappearance of ${ }^{125} \mathrm{I}$-insulin in three dog's (siblings) with the same ${ }^{125} \mathrm{I}$-insulin solution.

injection. The radioactivity was determined in $1.0 \mathrm{ml}$ of blood. The individual disappearance curve was obtained by plotting the log radioactivity of blood (cpm/ ml) versus time. After retropolation to origin the point of intersection was assumed as 100 percent. The initial linear part of the disappearance curve in the semilogarithmic system was the base for calculating the "initial half life" of ${ }^{125}$ I-insulin, which represents the distribution in the extracellular fluid.

2. Disappearance rate of IRI and alteration of metabolism after I.V. injection of bovine insulin (0.1 IU - tenfold recrystallized/kg body weight). Samples for analysis were taken from the hindleg vein at varying intervals for determination of plasma IRI [6], blood glucose [8], serum ILA [16] and serum glycerol [17]. The disappearance rate of IRI was deter- 
mined graphically in the same way as described above, except in immunized dogs, because the insulin antibodies in the serum interfered with antibodies of the assay. The initial linear part of the individual IRI disappearance curve in the semilogarithmic system was the basis for calculating the "initial half life" modified after Orskov and Christensen [14]. insulin by $\gamma$-globulins (Fig. 1) and an increased ${ }^{125} \mathrm{I}$ IBC $(20-50 \mu \mathrm{U} / \mathrm{ml}) .6$ weeks after the beginning of insulin-treatment the serum of the spontaneously diabetic dog also showed a binding of ${ }^{125}$ I-insulin by $\gamma$ globulins (immunoelectrophoresis and Sephadex G-200 filtration) and an increased ${ }^{125} \mathrm{I}-\mathrm{IBC}(30 \mu \mathrm{U} / \mathrm{ml})$. Fig. 2 shows the quantity of $125 I$-binding in the serum of all

Table 1. Behaviour of I. V.-injected insulin in vivo

\begin{tabular}{llll}
\hline & \multicolumn{2}{l}{$\begin{array}{l}\text { Initial intravasal disappearance } \\
\text { rate } t \frac{1}{2} \text { in minutes }\end{array}$} & $\begin{array}{l}\text { Biological action of unlabelled } \\
\text { insulin 15 min after injection }\end{array}$ \\
\hline Groups of dogs & of ${ }^{125}$ I-insulin & $\begin{array}{c}\text { of immunoreactive } \\
\text { insulin (IRI) }\end{array}$ & $\begin{array}{l}\text { Serum glucose in \% of start } \\
\text { values }\end{array}$ \\
\hline Dogs without any & 3.0 & 5.0 & 36 \\
insulin treatment & 2.5 & 4.0 & $\mathbf{3 5}$ \\
$n=3$ & $\mathbf{3 . 0}$ & $\mathbf{3 . 0}$ & 40 \\
Dogs adapted to insulin & 3.0 & $\mathbf{3 . 5}$ & $\mathbf{2 5}$ \\
$n=2$ & 4.0 & $\mathbf{2 . 5}$ & $\mathbf{3 4}$ \\
Dogs immunized against & 15 & & 75 \\
insulin & 40 & not determinable & 94 \\
$n=3$ & 22 & & $\varnothing$ \\
\hline
\end{tabular}

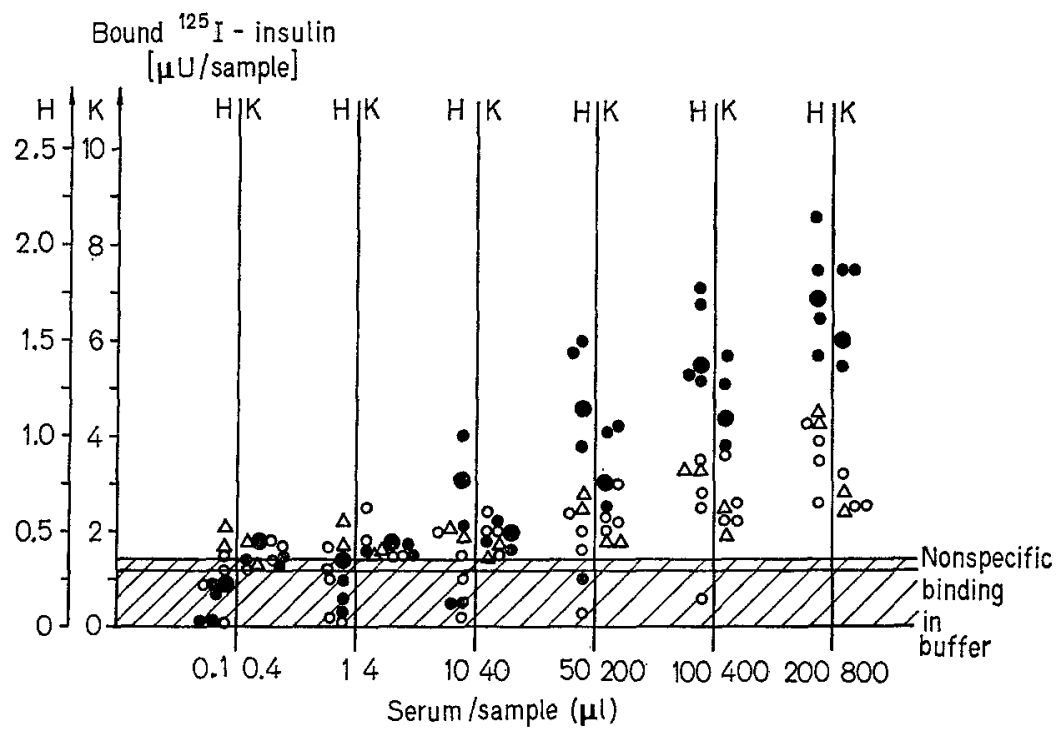

Fig. 3. ${ }^{125} \mathrm{I}$-insulin binding in serum. Determination by cellulose differential adsorption of free insulin (Kerp $=K$ ) and by ethanol, precipitation of bound insulin (Heding $=H$ ) in varying dilutions. Abscissa - $\mu$ l serum per sample; ordinate - bound ratio ${ }^{125} \mathrm{I}$-insulin in the sample

0 dog without any insulin treatment

$\triangle$ dog adapted to insulin

- dog immunized against insulin

- spontaneously diabetic dog treated with insulin

\section{Results}

Analytical procedures in vitro for detection of circulating insulin antibodies (Figs. 1 and 2). In all experiments there were no differences between the sera of the dogs adapted to insulin and the sera of the dogs which had never received insulin, i.e. insulin antibodies could not be found. In contrast to this, the serum of the immunized dogs in one case showed an immuno-precipitation of insulin and in all cases a binding of ${ }^{125} \mathrm{I}$ - dogs. The serum of one immunized dog was studied twice. After fractionation with acidic glycine buffer on Sephadex G-100, neither the serum of the dog adapted to insulin, nor the serum of the dogs which had never received insulin showed an ${ }^{125} \mathrm{I}$-binding in $\gamma$-globulins (immunoelectrophoresis with autoradiography) or an increase of IBC. Further references to the absence of antibodies against, insulin in the serum of dogs adapted to insulin may be seen in the normal level of insulin determined by radio-immunoassay. 
Experiments in vivo for detection of circulating insulin antibodies (Table 1, Fig. 3). As was the case in vitro, all experiments in vivo with labelled and unlabelled insulin showed no differences between the dogs adapted to insulin and the dogs which had never received insulin. The initial intravasal insulin disappearance rate was very short in these dogs $(2.5-5.0 \mathrm{~min})$. In the immunized dogs the graphical determination of ${ }^{125} \mathrm{I}$ insulin disappearance rate was rather inexact, but there is no doubt that in all cases the initial disappearance rate was delayed. Fig. 3 shows the individual curves of three experiments with the same ${ }^{125}$ I-insulin solution obtained on the same day. Corresponding to the retarded rate of entering the interstitial space, insulin acted on the metabolism of the immunized dogs later and less intensively. There is no difference in the biological action of I.V. injected insulin on the levels of glucose and glycerol between adapted dogs and dogs never treated with insulin. Corresponding to the rapid biological action of insulin in vivo, the ILA of serum declined exponentially to the base line within 10 to 20 min after a rapidly reached peak $(>2000 \mu \mathrm{U} / \mathrm{ml})$. In serum of immunized dogs, however, the ILA curve reached a lower peak $(600 \mu \mathrm{U} / \mathrm{ml})$ and developed a shoulder with a broad second peak $(440 \mu \mathrm{U} / \mathrm{ml})$ one hour after injection.

\section{Discussion}

Antibodies to exogenous insulin were observed in almost all subjects given insulin [1]. The immunoreaction of dogs against insulin is well marked $[11,5]$. Therefore we were surprised that our dogs failed to show circulating antibodies. We assume that the mode of insulin-application - the initially slowly increasing dose and the uninterrupted fractionated administration - has caused the non-appearance of antibodies. We want to discuss the possibility of an immunotolerance, although the final evidence - failure of appearance of antibodies after application of insulin in adjuvant - was not carried out, and we do not know what happens in the first period of insulin application.

The specific suppression of immunological reaction against insulin may be an advantage for patients with local allergy or with resistance to insulin, for the preservation of endogenous insulin secretion [10] and in regard to the development of complications of long standing diabetes [19]. The antigenicity of insulin decreases with increasing purity, otherwise an addition of depot material potentiates the formation of insulin antibodies $[4,3]$. No antibodies were found after treatment with porcine monocomponent insulin in neutral solution [18]. It was supposed that the reason for the extremely rare occurrence of insulin resistance in Scandinavia may be seen in the higher purity of the insulin used [3]. But the occurrence of insulin resistance on our patients is rare, too, though the normal insulin we use is always a mixture of bovine-porcine insulin, not highly purified. Out of all diabetics treated with commercial insulin in our institute from 1964 to 1967 (7927, i.e. 3884 females and 4043 males) we found 16 , i.e. 14 females and 2 males, with an insulin requirement greater than $100 \mathrm{IU} /$ day at discharge. Without doubting the importance of the quality of insulin we think that the quantity of the daily insulin doses is essentially determined by the traditional method of treatment; so that doses are often increased in patients with already high insulin-requirement, without real necessity for a further increase.

On the other hand, the concentration as well as the avidity of the antibodies, and thus the real insulin requirement, depends on the mode and the dose of the first and further antigen contacts. We prefer normal insulin injected three of four times daily, mostly in combination with a small dose of depot insulin. One injection is only allowed if the requirement is less than $20 \mathrm{IU} /$ day. Therefore we suggest that the occurrence of insulin-resistance not only depends on the purity of insulin but also partly on the mode of insulin application in the first and further treatments.

We cannot explain why the adapted dogs are able to tolerate such an amount of insulin daily, though the insulin sensivity after I.V.-injection was not diminished. According to similar experiments Mohnike [13] and Krüger [9] assumed an activation of hormonal insulinantagonists.

\section{Conclusions}

1. The beginning of the treatment with slowly increasing doses of insulin as well as the further uninterrupted treatment three times a day, may be the reason for the non-appearance of circulating insulin antibodies.

2. References were given in clinical practice as well as in experiments that the specific suppression or the avoidance of immuno-reactions against exogenous insulin is an advantage for the diabetic patient. The decrease of antigenicity of insulin by increasing purity and preference of porcine monocomponent-insulin may be important steps in this direction.

In our opinion the mode of subcutaneous application may be another method to protect diabetics against the immunological reactions to insulin.

Acknowledgements. We wish to thank Mrs. T. Haupt and Mrs. H, Ohlrich for technical assistance.

\section{References}

1. Berson, S.A., Yalow, R.S., Baumann, A., Rothschild, M. A., Newerly, K. : Insulin-I ${ }^{131}$ metabolism in human subjects: Demonstration of insulin binding globulin in the circulation of insulin treated subjects. J. clin. Invest. 35, 170-190 (1956).

2. Chao, P.J., Karam, J.H., Grodsky, G.M. : Insulin- ${ }^{131}$ binding in serum from normal and diabetic subjects by ultracentrifugation and gelfiltration. Diabetes 14, $27-32(1965)$. 
3. Deckert, T., Grundahl, E.: The antigenicity of pig insulin. Diabetologia 6, 15-20 (1970).

4. Fankhauser, S.: Neuere Aspekte der Insulintherapie. Schweiz. med. Wschr. 99, 414-420 (1969).

5. Fischer, U., Hommel, H., Michael, R., Bibergeil, H.: Insulin and insulin effect in the spontaneously diabetic dog. 7th. Congr. Int. Diab. Fed. Buenos Aires 23-28 VIII 70 Abstr. 22.

6. Hales, C.N., Randle, P.J.: Immunoassay of insulin with insulin-antibody precipitate. Biochem. J. 88, $137-146$ (1963).

7. Kerp, J., Steinhilber, S., Kasimir, H.: Ein Verfahren zum Nachweis insulinbindender Antikörper durch Differentialadsorption. Klin. Wschr. 44, 560-567 (1966).

8. Köhler, P.: Verbesserte Glukoseoxydasemethode zur Blutzuckerbestimmung im Routinebetrieb des klinischen Laboratoriums. Z. ges. inn. Med. 17, 674-676 (1962).

9. Krüger, G.: Zur Frage des Adaptationsvermögens des tierischen Organismus gegenüber Insulin. Dissertationsschrift Med. Fak. Greifswald 1969.

10. Lee, J.C., Grodsky, G.M., Caplan, J., Graw, L.: Experimental immune diabetes in the rabbit. Amer. J. Path. 57, 597-616 (1969).

11. Menzel, R., Ziegler, M.: Nachweis von zirkulierenden Insulinantikörpern beim Hund. Endokrinologie 56, $334-336(1970)$.

12. - - Fehlende immunogene Wirkung exogenen Insulins bei Hunden nach langsamer Adaptation an Insulin. Experientia 26, 906-907 (1970).
13. Mohnike, G.: Adaptation und Dekompensation bei hochinsulinierten Meerschweinchen. Z. ges. exp. Med. 120, 23-50 (1952).

14. Orskov, H., Christensen, N.J.: Plasma disappearance rate of injected human insulin in juvenile diabetic, maturity-onset diabetic and nondiabetic subjects. Diabetes 18, 653-659 (1969).

15. Ouchterlony, Ö.: Antigen-antibody reactions in gels. Acta path. microbiol. Scand. 26, 507-515 (1949).

16. Renold, A.E., Martin, D.B., Dagenais, Y.M., Steinke, J., Nicerson, R.J., Sheps, M.C.: Measurement of small quantities of insulin-like activity using rat adipose tissue. J. clin. Invest. 39, 1487-1498 (1960).

17. Schäfer, H.: Die enzymatische Bestimmung von Glycerin im Blut. Wiss. Z. d. Univ. Greifswald 17, $364-365$ (1968).

18. Schlichtkrull, J.: Proinsulin and monocomponentinsulin. 6th Ann. Meeting of the Europ. Ass. Study of Diabetes, Warsaw 1970, Abstr. No. 171.

19. Wehner, H., Schade, U., Tiebermeister, E., Veigel, J. Glomeruläre Veränderungen nach Immunisierung mit heterologem Insulin. Virchows Arch., Abt. A Path. Anat. 349, 345 (1970).

20. Welborn, T.A., Richards, R., Fraser, T.R.: Simple test for insulin antibodies in serum, using ${ }^{131} \mathrm{I}$-insulin and ethanol precipitation. Brit. med. J. 1967 I, $719-$ 722.

Dr. Ruth Menzel

Zentralinstitut für Diabetes

„Gerhardt Katsch"“

DDR-2201 Karlsburg 